\title{
Bio-ecological study of the water mites (Acari: Hydracarina) of the pond of El-Goureate in the National Park of El-Kala (North-East of Algeria)
}

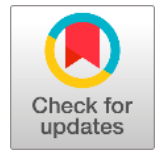

\author{
Samia Messikh ${ }^{a}$ Samir Djemlia ${ }^{*}$ (D) | Abdelkrim Tahraoui ${ }^{\text {(iD }}$ |
}

Applied Neuroendocrinology Laboratory, Department of Biology, Faculty of Science, Badji Mokhtar Annaba University Algeria, Algeria.

Corresponding author: s_djemli@yahoo.fr

\begin{abstract}
This study aimed to present faunistic and ecological data on aquatic mites living in small permanent basins and selected lakes in the El-Kala National Park (Northeast of Algeria). Thus, this study shows the research of Hydracarina in the park comprehensively over the two years. We have identified the living Hydracarina species in the semi-temporary study site at Goureate pond. The existence of an unknown and interesting Hydracarina fauna has been revealed. The collection of specimens revealed the presence of 9 species divided into 5 families. The identification required the study of ecological indices and the measurement of physicochemical parameters (temperature, humidity). The results of the univariate analysis of variance test fixed model, applied to each of the 9 physicochemical variables and a variable related to the number of Hydracarina, for two years. The results showed a very highly significant difference for water temperature and atmospheric temperature and a just significant difference for the number of Hydracarina, while no significant difference for $\mathrm{pH}$, humidity, conductivity, $\mathrm{NO}_{2}^{-}, \mathrm{PO}_{4}^{-}, \mathrm{NH}_{4}^{+}$is registered, and the study of the abundance of the identified species in the four stations during the four seasons.
\end{abstract}

Keywords biodiversity, El-Kala National Park, Hydracarina, physicochemical parameters

\section{Introduction}

The study and organization of ecosystems is currently a fundamental aspect in the knowledge of the factors that alter habitats and biodiversity. Knowledge of wetlands can only be envisaged after a study of their overall functioning for the RAMSAR Convention, wetlands are defined as areas of ponds, fens, peat bogs or artificial or natural, permanent or temporary, fresh or saltwater (Skinner and Zalewski 1995).

Freshwater that is part of the hydrosphere is of great importance to the global economy. More than a century ago the number of ponds was 10 times greater, their disappearance is mainly due to the new agricultural practices of this century, and the ponds have a depth that does not exceed $1 \mathrm{~m}$. Moreover, the world of insects is very vast and still with very little known, including by the ponds of which they represent an extraordinary biotope with a very large part of the diversity of living beings.

The richness of micro-habitats conditions biodiversity. Then many environmental characteristics select the presence of species (flow rate, temperature, water quality, nature of the substrate, light, among others) because gill respiration makes them more sensitive to the quality of the water and its dissolved oxygen content.

Insects form an extremely diverse class with great importance for ecosystems (Wigging, 1983). They participate in the full range of natural processes essential to the maintenance of biological systems and are becoming increasingly important in research, where the ecological importance of the immense variety of insects makes them useful in assessing disturbances or environmental impacts of various types.

Aquatic insects are the largest and most diverse animal group on the planet, while it is also one of the most poorly known. It is estimated that there are more than a million species of insects on earth, while only about 892,000 species are described. However, in addition to their numerical importance, the interest of insects lies in their remarkable diversity of forms and adaptation, which has enabled them to colonize the entire globe in practically all biotopes, except the oceans. (Messikh and Benyacoub 2015).

Among the aquatic arthropods, Hydracarina has been studied as an object of our theme because they are very colorful and present in all fresh and stagnant waters. They can be considered as true ecological indicators because of their habitat preferences (Peyrusse and Bertrand, 2001), but also because these organisms are linked to other biological components of the ecosystem by complex relationships of predation, phoresis, and parasitism (Peyrusse and Bertrand, 2001).

Hydracarina are carnivorous, they feed on worms, crustaceans, and especially insect larvae, and they seem to be repellent to predatory insects and also to fish, which explains why they can approach odonate larvae (Peyrusse \& Bertrand, 2001). The host-mite relationships are varied: the host may be parasitized for the completion of the cycle, the phonetic phase is an obligatory passage, which explains the dominance of some species from one station to another, but 
for a certain number of species, the cycle is not known (Peyrusse \& Bertrand, 2001). The first work on Hydracarina in the world was carried out by Cook (1957, 1974), Mitchell (1958), de Mullen (1975), Smith \& Cook (1991), Harvey (1998). Several researches have carried out an inventory of the Hydracarina fauna. In New Guinea, 75 species have been identified, 19 of which are newly described as subspecies (Wiles, 1997b). The Hydracarina of France are established by Peyrusse \& Bertrand, (2001), who revealed the presence of 420 species and 7 subspecies. Seven species have been newly identified in the Himalayas in India. In Turkey, 23 families, 55 genera, and more than 240 species of Hydracarina are known (Erman et al., 2010). For the Romanian fauna 56 species of Hydracarina have been identified, 40 of which are presented for the first time (Cimpean, 2010). And in Algeria, the first works are those of Lucas (1849), Gros (1904), the Sergent brothers (1904), Walter (1924, 1925, 1940), and Gauthier (1928, 1931) in Algiers, La Calle, Oran, Djurdjura and ElHoggar. Currently, work carried out by Algerian researchers has led to the classification and inventory of the lakes in the El-Kala region (Messikh and Benyacoub 2015; Messikh 2016), as well as of some ponds such as Mellah and Bouredim, which are listed and classified as study areas. This work has determined that Hydracarina are insect predators.

The aim of our work is the study of the entomological fauna related to the aquatic environment, at the same time as a contribution to the knowledge of the fauna of the pond of El-Goureate in which, as the entomological fauna has been little informed, it tries to shed some light on the ecology of aquatic insects in this pond and to determine the physicochemical characteristics of the water.

\section{Materials and Methods}

\subsection{General description and location of El - Kala National Park (P. N. E, K.)}

The National Park of El-Kala (P.N.E.K) is one of the largest national parks in Algeria and the Western Mediterranean. It was created by decree on July 23rd, 1983 and since 1990, it is classified as a Biosphere Reserve in the network of reserves of the MAB (Man and Biosphere) program of UNESCO. It gathers nine communes entirely contained in the wilaya of El-Taref (wilaya resulting from the administrative division of the year 1985). This integral reserve covers an area of 76,000 ha, or $26 \%$ of the wilaya's surface area (Figure 1). The park is naturally limited to the north by the Mediterranean coast, to the west by the dune system of Righia and the plains of Annaba, to the east by the AlgerianTunisian borders and to the south by the foothills of the Medjerda mountain (Djebel Ghorra). This territory is characterized by the existence of five major types of habitats of high ecological value. Forest habitat, wetlands (the Oubeira, Tonga, and Bird Lakes are classified as Ramsar sites), rocky habitat, dune habitat, and coastal habitat. Characterized by an important mosaic of ecosystems, the
PNEK is home to a rich and diverse fauna and flora. Its geographical coordinates are 36'52 latitude north and 8"27 longitude east, at the level of the city of El-Kala.

\subsection{General description and location of the El-Goureate pond}

Located at $36^{\circ} 50^{\prime} 45,6^{\prime \prime} \mathrm{N}, 08^{\circ} 10^{\prime} 30^{\prime \prime} \mathrm{E}$, its altitude is $23 \mathrm{~m}$. It is located in an old dune formation covered with a Kèrmes oak scrub, mastic, and calycotome. It corresponds in fact to the exsurgence of the dune sheet, having an approximate area of 06 ha and a depth varying from 0.6 to 1 $\mathrm{m}$. The body of water depends entirely on the rhythm of the beating of the tablecloth. It has experienced some complete drying out (Figure 1).

\subsection{Sampling method}

Adult water mites were collected from the four stations, during one trip per month for two years. Samples too were taken from their shallower parts (at depths of up to $0.5 \mathrm{~m}$ ). First, we measured the chemical and physical parameters, where we using a multi-parameter device (CONSORT 535). Water temperature was measured with an accurate thermometer. Nutrients' test $\left(\mathrm{NO}_{2}^{-}, \mathrm{PO}_{4}^{-}, \mathrm{NH}_{4}^{+}\right)$, with visocolor ECO: (the Test kit). Finally, the conductivity is expressed in $(\mu \mathrm{s} / \mathrm{cm})$. At the same time, we examined and checked carefully the water, here where many mites have a contrasting appearance, because of their bright coloration and movements. Also, it's important to know that they are free-swimming and crawling on aquatic plants and moss. After all, we picked up some mites quickly with a box size of 0.5 liters, later we transported them to the laboratory, where we prepared them for study. PS: Test Kit for performing colorimetric tests on nitrite ions in surface water and sewage.

\subsection{Conservation and mounting plates}

Adult mites were be preserved in Modified Koenike's solution (or GAW), consisting of 5 parts glycerine, 4 parts water, and 1 part glacial acetic acid, by volume (Barr, 1973), so that they can be properly cleared and slide-mounted for identification and study. Adults must be cleared in either acetic corrosive or $(10 \% \mathrm{KOH})$ and mounted in glycerine jelly. The observation was made with a Microscope objective (10x and 40x). We used the keys (Cook, 1974; Proctor, 2006) for identifying the families and species found.

\subsection{Statistical analyses}

We calculated the basic statistical as means \pm standard deviation (SD) of eight variables of the physical and chemical parameters for every station. The significance of results was tested by analysis of variance (ANOVA) followed by a Tukey's test. All statistical analyses were calculated using MINITAB Software (Version 16) and $p<0.05$ was considered to be a statistically significant difference. The Shannon index with a base 2 logarithm was used for analysis and we conducted the CPA factorial analysis type (Pearson (n)) between speciesparameters. 


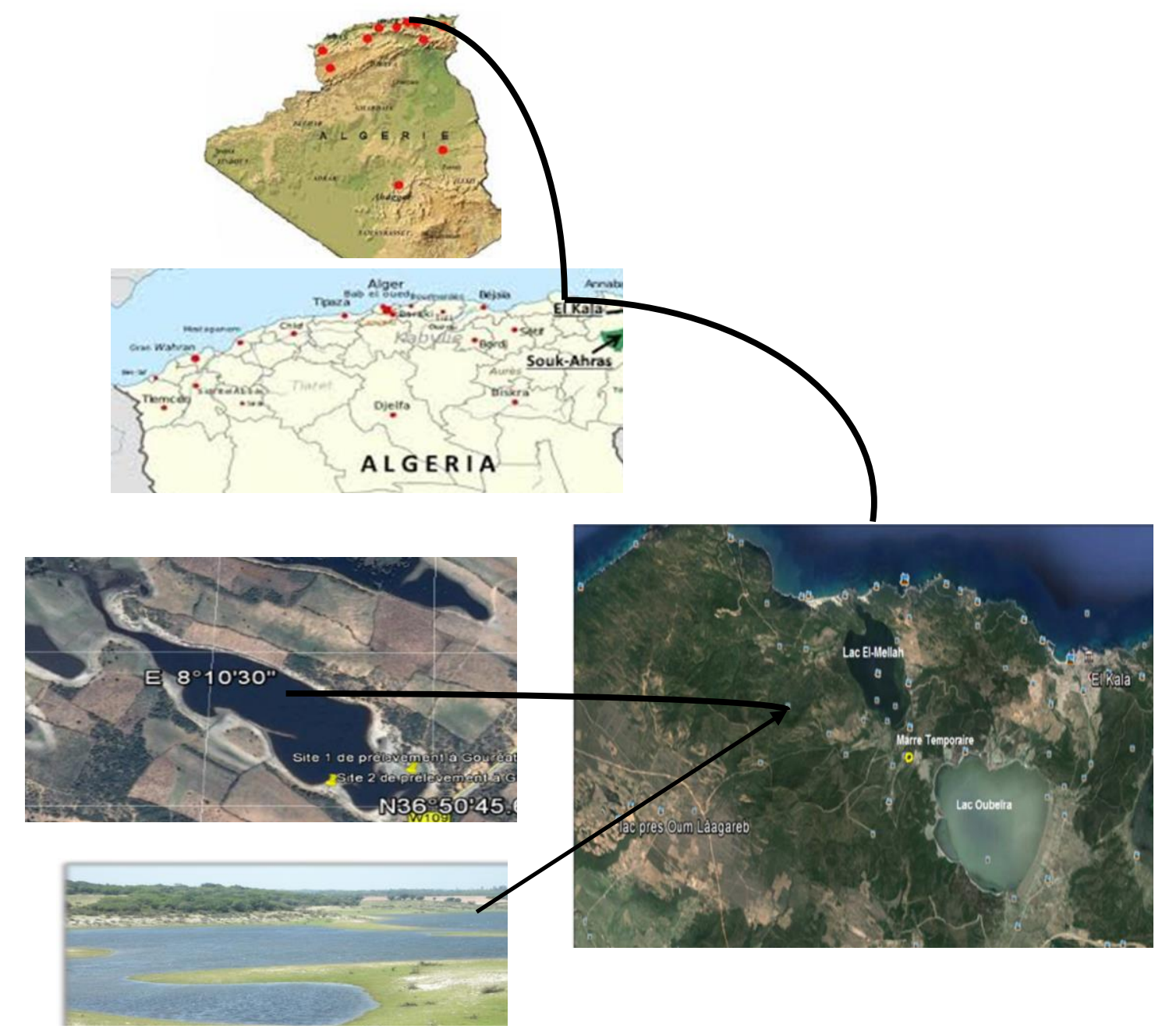

Figure 1 General description and location of the pond of El-Goureate in El - Kala National Park (P. N. E, K.).

\section{Results and Discussion}

\subsection{Biometric characteristics}

In the El-Goureate pond, 107 individuals were collected, it is Eylais hamata, a species that numerically dominates all species with $23 \%$ (25 individuals), followed by Piona alpicola with a percentage equal to $19 \%$ (20 individuals) (Figure 2).

\subsection{Physical and chemical characteristics of the station}

In general, the monthly average of the physical data of the El-Goureate pond is represented by the maximum average $\mathrm{pH}$ value in July, which is 7.21 and a minimum value of 5.44. The water temperature varies from $12.85^{\circ} \mathrm{C}$ to 31.45 ${ }^{\circ} \mathrm{C}$, with a maximum conductivity of $586(\mu \mathrm{s} / \mathrm{cm})$ and a minimum of $364.5(\mu \mathrm{s} / \mathrm{cm})$. On the other hand, the air temperature values are between a minimum value of $14.6^{\circ} \mathrm{C}$ and a maximum value of $32.6^{\circ} \mathrm{C}$, with a high value of $60.30 \%$ and a minimum value of $40.5 \%$ for humidity.

The monthly average of the chemical data of the water in the El-Goureate pond indicates that the nitrite values are between $0.01 \mathrm{mg} / \mathrm{ml}$ and $0.055 \mathrm{mg} / \mathrm{ml}$. For phosphate, the minimum value is $0.2 \mathrm{mg} / \mathrm{ml}$ and the maximum value is 1.55 $\mathrm{mg} / \mathrm{ml}$, also the maximum value for ammonium is $1.55 \mathrm{mg} / \mathrm{ml}$ but the minimum value of $0.1 \mathrm{mg} / \mathrm{ml}$ (Figure 3).

\subsection{Correlation between physicochemical parameters and the number of Hydracarina}

\subsubsection{Comparison between seasons and the 9 variables in the El-Goureate pond}

The results of the univariate analysis of variance test fixed model, applied to each of the 9 physicochemical variables and a variable related to the number of Hydracarina, for two years, are shown in Table 1 related to the El-Goureate pond. They show a very highly significant difference for water temperature and atmospheric temperature and a just significant difference for the number of Hydracarina, while no significant difference for $\mathrm{pH}$, Humidity, conductivity, $\mathrm{NO}_{2}^{-}, \mathrm{PO}_{4}^{-}, \mathrm{NH}_{4}^{+}$is registered. 


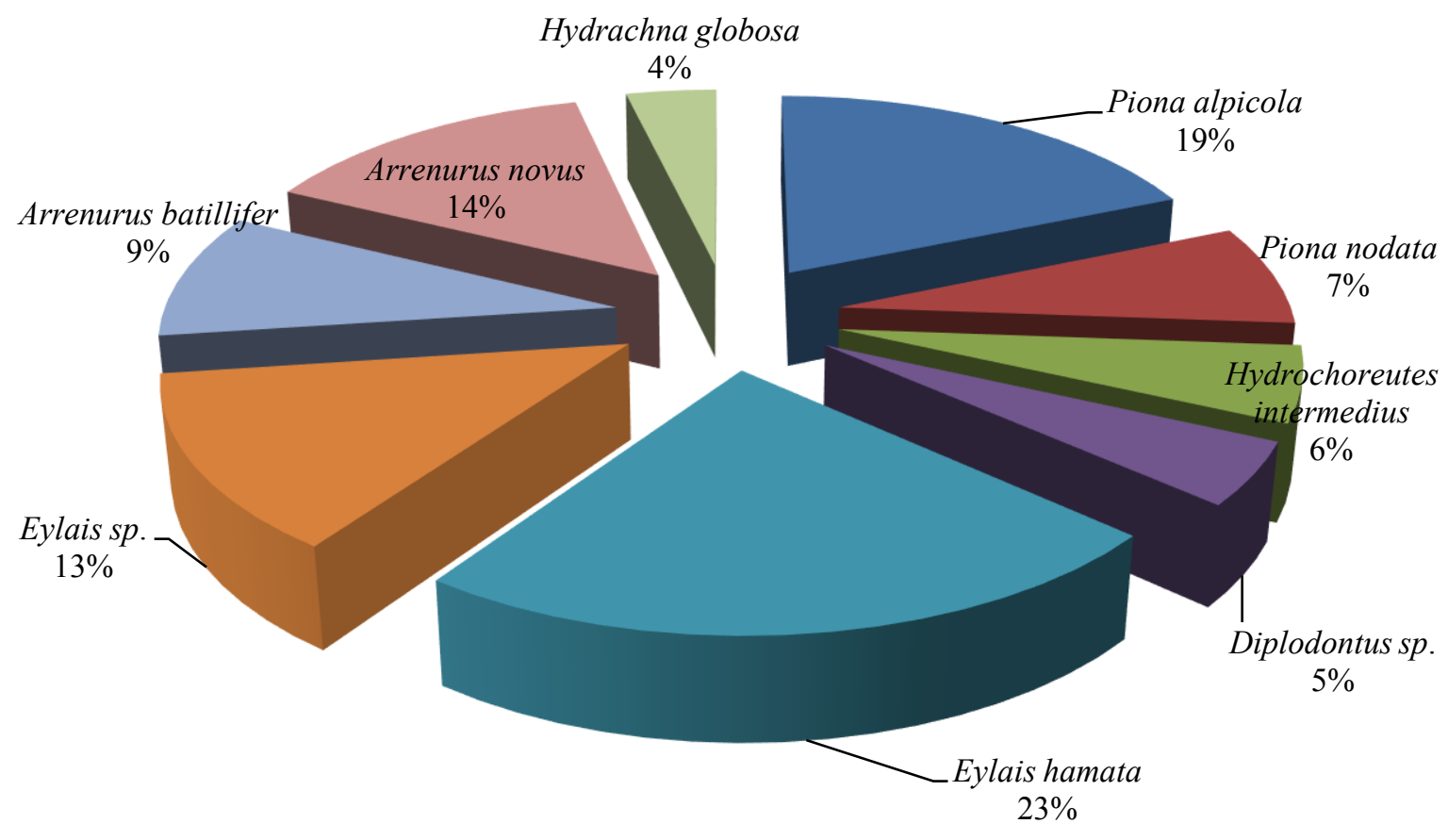

Figure 2 Centesimal frequency of the total species of water mites in the El-Goureate pond in El-Kala National Park.

Table1 Analysis of variance at a fixed model classification criterion of the comparisonbetween the seasons and the 9 variables relative in the El-Gourate pond.

\begin{tabular}{ccccccc}
\hline Variables & Sources of variation & ddl & SCE & $\mathrm{CM}$ & $\mathrm{F}$ obs & $P$-value \\
\hline $\mathrm{pH}$ & seasons & 3 & 1.5447 & 0.5149 & 1.05 & $0.398 \mathrm{~ns}$ \\
$\mathrm{~T}^{\circ}$ Eau $\left({ }^{\circ} \mathrm{C}\right)$ & seasons & 3 & 633.47 & 211.16 & 10.55 & $0.000^{* * *}$ \\
$\mathrm{~T}^{\circ} \mathrm{Atm}\left({ }^{\circ} \mathrm{C}\right)$ & seasons & 3 & 639.30 & 213.10 & 15.72 & $0.000^{* * *}$ \\
Humidity $(\%)$ & seasons & 3 & 88.2 & 29.4 & 0.24 & $0.866 \mathrm{~ns}$ \\
Conductivity $(\mu / \mathrm{cm})$ & seasons & 3 & 23849 & 7950 & 0.47 & $0.708 \mathrm{~ns}$ \\
$\mathrm{NO}_{2}(\mathrm{mg} / \mathrm{ml})$ & seasons & 3 & 0.001363 & 0.000454 & 0.40 & $0.757 \mathrm{~ns}$ \\
$\mathrm{PO}_{4}(\mathrm{mg} / \mathrm{ml})$ & seasons & 3 & 1.4949 & 0.4983 & 1.18 & $0.348 \mathrm{~ns}$ \\
$\mathrm{NH}_{4}(\mathrm{mg} / \mathrm{ml})$ & seasons & 3 & 4.025 & 1.342 & 0.86 & $0.480 \mathrm{~ns}$ \\
$\mathrm{Number}$ & seasons & 3 & 166.93 & 55.64 & 4.10 & $0.023^{*}$ \\
\hline
\end{tabular}

The statistical analysis using CPA in the $1 \times 2$ factorial (Figure 4), design then resembles $(31.82+20.37=52.19 \%)$ performed by the Minitab16 software (ref) exposes us a graph that Axis1 (ordered): $31.82 \% \rightarrow$ opposes all the species / to the physicalchemical analyses

Where the most important is: $\mathrm{NO}_{2}{ }_{2}$ and then can explain the distribution of species. The species: Eylais hamata; Eylais sp; Arrenurus novus, characterized by the $\mathrm{NO}_{2}^{-}$level mainly collected during observation Hydrochoreutes intermedius; Hydrachna globosa; Diplodontus sp; Arrenurus batillifer; Piona nodata; Piona alpicola (observation 16 then 7, 17, 12 and 2).
Axis 2 (absence): $20.37 \% \rightarrow$ opposes on one side the $\mathrm{NO}_{2} 2$ is linked to the water temperature and $\mathrm{pH}$. And on the other side opposes all species: Hydrochoreutes intermedius; Hydrachna globosa; Diplodontus sp; Arrenurus batillifer; Piona nodata; Piona alpicola are linked to Conductivity, $\mathrm{PO}_{4}^{-}$, and $\mathrm{NH}_{4}^{+}$.

Correspondence Factory Analysis Plan 1-2. This plane totals $80 \%$ of the variance of the scatterplot (Figure 5 ).

Axis 1 , which represents more than $61 \%$ of the variance, opposes the species Arrenurus batillifer, Piona nodata, Hydrachna globosa, Hydrochoreutes intermedius, Diplodontus $s p$. in its positive part to Eylais sp. Eylais hamata positioned in its negative part. 
Table 2 Groups of homogeneous seasons by variables in the El-Goureate pond.

\begin{tabular}{|c|c|c|c|}
\hline Variables & $\begin{array}{c}\text { Sources } \\
\text { of variation }\end{array}$ & Group A & Group B \\
\hline & $\mathrm{H}$ & Gouréate & \\
\hline \multirow[t]{4}{*}{$\mathrm{pH}$} & $P$ & Gouréate & \\
\hline & $E$ & Gouréate & \\
\hline & A & Gouréate & \\
\hline & $\mathrm{H}$ & & Gouréate \\
\hline \multirow[t]{4}{*}{$\mathrm{T}^{\circ} \mathrm{Eau}$} & $P$ & & Gouréate \\
\hline & $\mathrm{E}$ & Gouréate & \\
\hline & A & & Gouréate \\
\hline & $\mathrm{H}$ & & Gouréate \\
\hline \multirow[t]{4}{*}{$\mathrm{T}^{\circ} \mathrm{Atm}$} & $P$ & & Gouréate \\
\hline & $\mathrm{E}$ & Gouréate & \\
\hline & A & & Gouréate \\
\hline & $\mathrm{H}$ & Gouréate & \\
\hline \multirow[t]{4}{*}{ Humidity } & $P$ & Gouréate & \\
\hline & $\mathrm{E}$ & Gouréate & \\
\hline & A & Gouréate & \\
\hline & $\mathrm{H}$ & Gouréate & \\
\hline \multirow[t]{4}{*}{ Conductivity } & $P$ & Gouréate & \\
\hline & $\mathrm{E}$ & Gouréate & \\
\hline & $A$ & Gouréate & \\
\hline & $\mathrm{H}$ & Gouréate & \\
\hline \multirow[t]{4}{*}{$\mathrm{NO}_{2}^{-}$} & $P$ & Gouréate & \\
\hline & $\mathrm{E}$ & Gouréate & \\
\hline & A & Gouréate & \\
\hline & $\mathrm{H}$ & Gouréate & \\
\hline \multirow[t]{4}{*}{$\mathrm{PO}_{4}$} & $P$ & Gouréate & \\
\hline & $\mathrm{E}$ & Gouréate & \\
\hline & A & Gouréate & \\
\hline & $\mathrm{H}$ & Gouréate & \\
\hline \multirow[t]{4}{*}{$\mathrm{NH}_{4}^{+}$} & $P$ & Gouréate & \\
\hline & $\mathrm{E}$ & Gouréate & \\
\hline & $A$ & Gouréate & \\
\hline & H & Gouréate & \\
\hline \multirow[t]{3}{*}{ Number } & $P$ & Gouréate & \\
\hline & $\mathrm{E}$ & & Gouréate \\
\hline & $A$ & Gouréate & \\
\hline
\end{tabular}

Table 3 Total richness and average of the 9 species in the El-Goureate pond.

\begin{tabular}{cc}
\hline Stations & \\
Especes & d'El-Goureate \\
\hline Piona alpicola & 18,69 \\
Piona nodata & 7,47 \\
Hydrochoreutes intermedius & 5,60 \\
Diplodontus sp & 4,67 \\
Eylais hamata & 23,36 \\
Eylais sp & 13,08 \\
Arrenurus batillifer & 9,34 \\
Arrenurus novus & 14,01 \\
Hydrachna globosa & 3,73 \\
Effective/station & 107 \\
H'/ station & 2,92 \\
S /station & 9 \\
H'max & 3,17 \\
E/station & 0,92 \\
\hline
\end{tabular}


$\mathbf{T}^{\circ}$ air

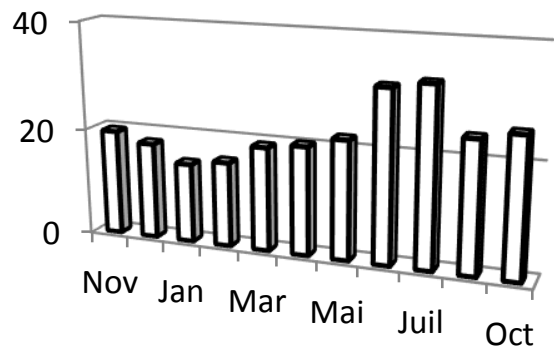

Humidity \%

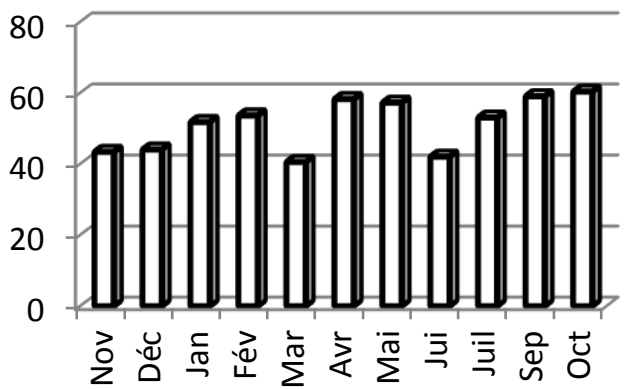

Conductivity

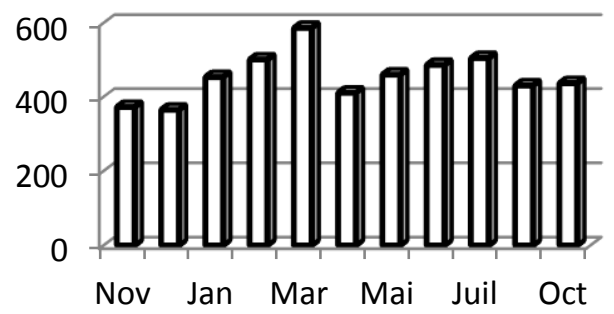

$\mathrm{PO}_{4}^{-}$

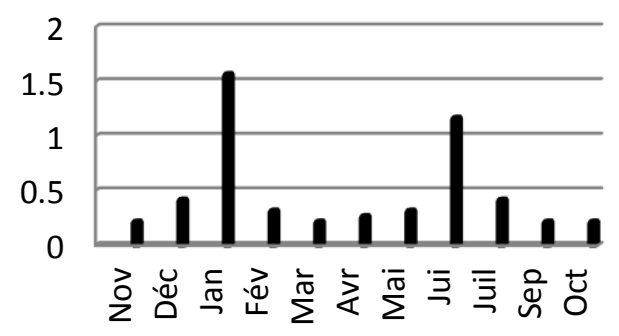

$\mathbf{T}^{\circ}$ eau

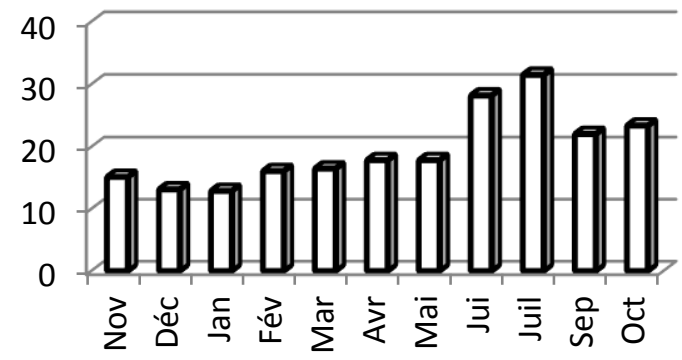

pH

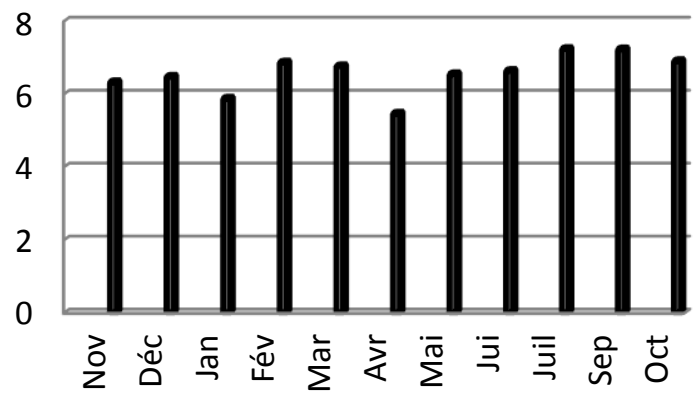

$\mathrm{NO}_{2}^{-}$

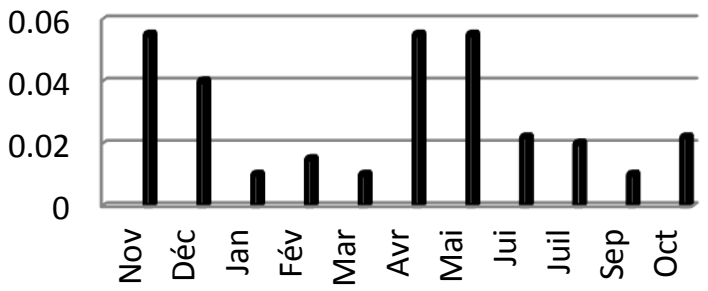

$\mathrm{NH}_{4}^{+}$

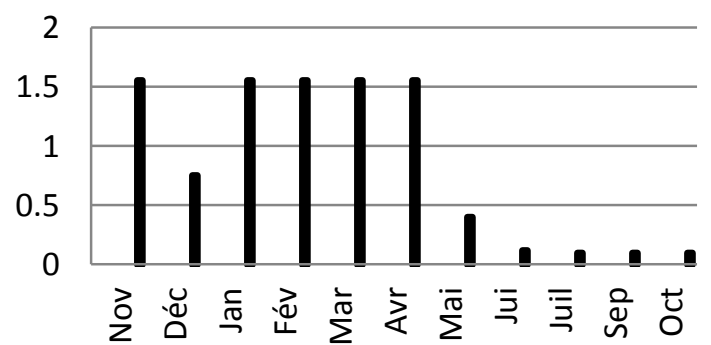

Figure 3 Analysis of the physicochemical parameters of the water at the El-Goureate pond.

The first group of species seems to be associated, in this station, with the vernal period, i.e. roughly spring. Besides, the concentration of ammonium ions, represented by the vector $\mathrm{NH}_{4}^{+}$, probably constitutes the most discriminating variable for this group of species at this period.

The second group of species, Eylais sp, Arrenurus novus, Eylais hamata seems to be associated rather with the autumn and winter period. The $\mathrm{pH}$ of the water constitutes, moreover, the determining factor of their presence in this station, in the sense that they are species preferring $\mathrm{pH}$ rather close to neutral.

Axis 2 discriminates Piona alpicola and Arrenurus novus in its negative part and associates them to the water temperature. These species are probably sensitive to the cooling of their living environment. The rest of the axes provide little additional information. 


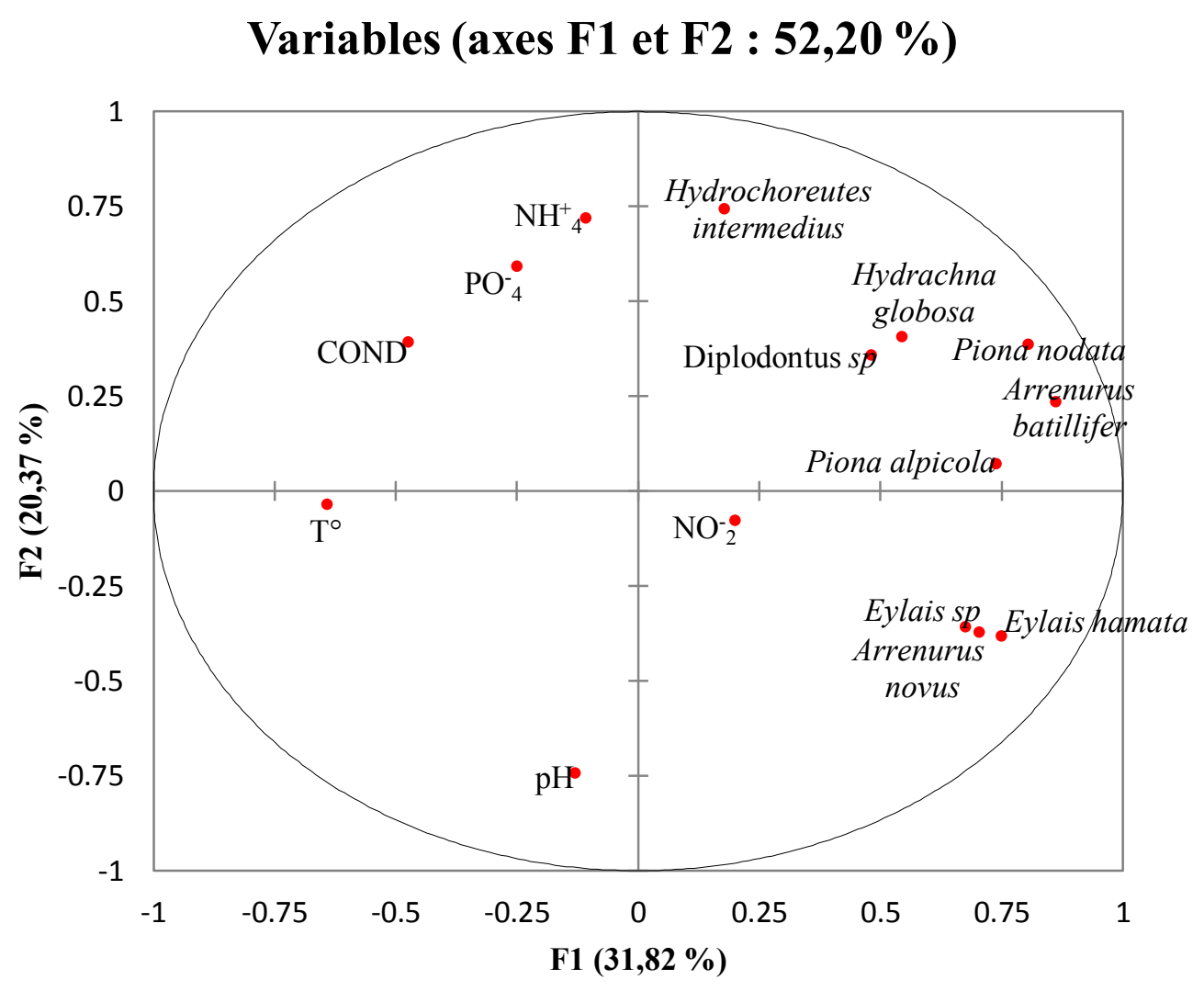

Figure 4 The principal component analysis species-Physico-chemical.

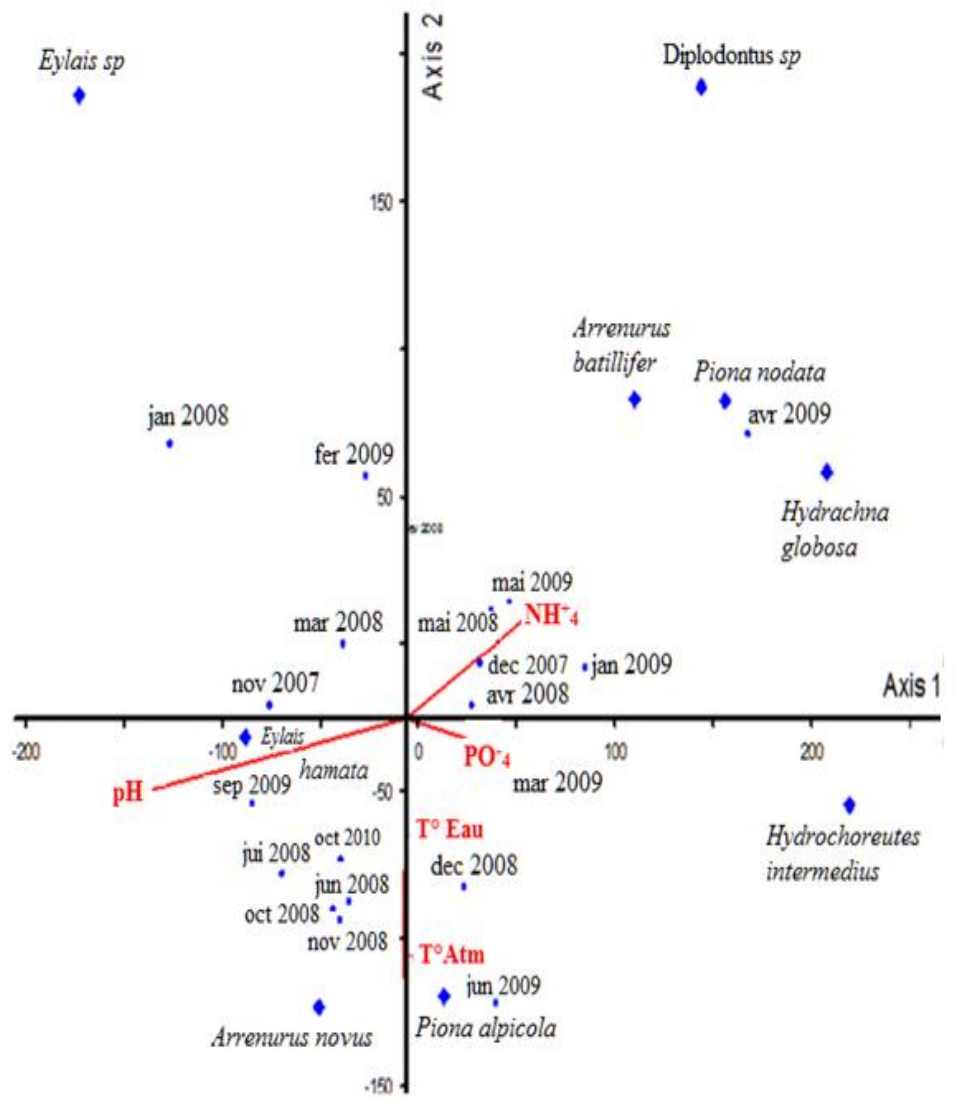

Figure 5 Parameters Factorial Correspondence Analysis of the Species-Variable Matrixfor the two years of study in the El-Goureate pond. 


\section{Conclusions}

This work was carried out in the region of EL-Kala, one of the most important wetlands in the north-eastern region of Algeria, both in the ecological (biological wealth) and economic framework. The sites indicated mainly concern the study of some physicochemical characteristics of the waters.

Among the ecological factors which are at the origin of the selection of certain biological types is first of all the water regime. The flow of rainwater can be immediate for a short period, it is the rainfall regime in which the cycle of Hydracarina via the development of the egg at the time of egg-laying by females from spring to late summer.

\section{Conflict of Interest}

The authors declare that they have no conflict of interest.

\section{Funding}

This research did not receive any specific grant funding agencies in the public, commercial, or not-for-profit sectors.

\section{References}

Messikh S, Benyacoub S (2015) Research on the Ecology of Water Mites (Acari: Hydracarina) in North-East of Algeria (Wetland Complex of El-Kala National Park). Annual Research \& Review in Biology 5:238-245, 2015.

Messikh S (2016) Etude Bio-écologique des Hydracariens de la région d’EI Kala. Thèse de doctorat, univ, Annaba. Algeria.105 p.

Skinner J, Zalewski S (1995) Fonction et valeurs des zones humides méditerranéennes. Tour du Valat, Arles (France), N'2.88. Pub. MedWet.

Peyrusse V, Bertrand M (2001) Les acariens aquatiques de France. Insectes 123:3-6.

Cook DR (1957) Order Acarina.Sub-order Hydracarina. Genus Protoarrenurus Cook, n. gen. Pages 248 - 249 In: A. R. Palmer, editor, Miocene Arthropods from the Mojave Desert, California. Geological Survey professional Paper (U. S.) No. 294-G.

Mitchell R (1958) Sperm transfer in the water mite Hydryphantes ruber Geer. American Midland Naturalist 60:156-158.
Mullen GR (1975) Predation by water mites (Acarina: Hydrachnellae) on immature stages of mosquitoes. Mosquito News 35:168-171.

Smith IM, Cook DR (1991) Water Mites. In: Thorp, J. \& Covich, A. (eds): Ecology and Classification of North American Freshwater Invertebrates. Academic Press, San Diego: 523-592p.

Harvey MS (1998) The Australian Water Mites.A guide to families and genara. Monographs on Invertebrate Taxonomy 4:1-150.

Cook DR (1974) Water mite genera and subgenera.Memoirs of the American Entomological Institute 21:860.

Erman O, Pešic V, Esen Y, Özkan M (2010) A checklist of the water mites of Turkey (Acari: Hydrachnidia) with description of two new species. Zootaxa 2624:1-48.

Cimpean M (2010) Taxonomical and ecological study of water mite communities (Acari, Hydrachnidia) from the river Somesul Mic catchment area and their role as indicators of water quality Babes- Bolyai University, Cluj-Napoc Biology and Geology Faculty Taxonomy and Ecology Department. $31 \mathrm{p}$.

Lucas H (1849) Histoire naturelle des animaux articulés. Exploration scientifique de l'Algérie pendant les années 1840, 1841, 1842. Sciences physiques. Zoologie 1. Bd. 1, Crustacés, Arachnides, Myriapodes et Hexapodes, 403 p. Imprimerie Nationale, Paris.

Gors H (1904) Sur un acarien parasite des amopléles, C. R. Scia. C. Soc. Bio.56, $57 \mathrm{p}$.

Sergent E (1904) Note on the parasite mites of Anopheles. Report of the Biology Society 56:100-102.

Walter C (1924) Quelques espèces nouvelles d'hdracariens du Maroc et du Soudan. Bull. Soc. Sci. natur. 4:61-71.

Walter C (1925) Hydracariens de l'Algérie et de la Tunisie (Collections de M. H. Gauthier), Première liste. Bull. Soc. Hist. Natur. Afrique Nord 16:189-238. Walter C (1940) Hydracarina of Algeria. Ann. Mag. Hist. Natur. 5:513-518.

Gauthier HC (1928) Recherches surb la faune des eaux continentales de I'Algérie et de la Tunisie-Alger, Impr. Minerva, 420p.

Gauthier HC (1931) Faune aquatique du Sahara central. Récoltes de M.L. Seurat au Hoggar en 1928 - Bull. Soc. Hist. Natur. Afrique Nord 22:350-400.

Angelier E, Angelier ML, Lauga J (1985) Recherches sur l'écologie des hydracariens (Hydrachnellae, Acari) dans les eaux courantes. Annls Limnol 21:25-64. 